\title{
Branched-chain Amino Acids for Use as a Nitrogen Source on Creeping Bentgrass
}

\author{
Isaac T. Mertz ${ }^{1}$, Nick E. Christians ${ }^{1}$, and Adam W. Thoms ${ }^{1}$
}

Additional index words. Agrostis stolonifera, fertilizer, golf, shoot density, turfgrass

Summary. Amino acids have been reported to improve turfgrass growth compared with mineral nutrition; however, amino acid catabolism in plants has not been well studied. A number of turfgrass fertilizers contain amino acids; however, some amino acids may be more effective additives in fertilizers than others. Three amino acids that could be effective nitrogen sources for plant growth are the branchedchain amino acids (BCAAs). The BCAA leucine (L), isoleucine (IL), and valine (V) could be effective additives because they are nonpolar and hydrophobic, which can promote plant uptake of these compounds. Although the effect of exogenously applied BCAA on plant growth is not well known, BCAAs have been reported to increase protein synthesis in humans, and that rate of increase is related to the intake ratio of $\mathrm{L}$ to $\mathrm{IL}$ and $\mathrm{V}$. The objective of this study was to evaluate the use of $\mathrm{L}, \mathrm{IL}$, and $\mathrm{V}$ as a nitrogen sources on creeping bentgrass (Agrostis stolonifera) and to investigate the effect of BCAAs on plant growth when all three are applied as a combination. Using specially made rooting tubes, $\mathrm{L}, \mathrm{IL}$, and $\mathrm{V}$ were applied in a complete factorial and compared with equal urea nitrogen at four rates, as well as an untreated control. Where all three BCAAs were applied in combination, the application ratios of 2:1:1 and 4:1:1 (L:IL:V) were tested. At 63 days after seeding, there were no differences in root length, root weight, or shoot weight; however, BCAA 2:1:1 and 4:1:1 increased creeping bentgrass shoot density by $24 \%$ and $32 \%$, respectively, compared with equal urea nitrogen. Where shoot density was increased, nitrogen application rate had no effect. On the basis of these results, BCAAs applied in a complete combination using ratios of $2: 1: 1$ or $4: 1: 1(3.03 \mathrm{lb} /$ acre $N)$ will provide a greater creeping bentgrass shoot density compared with equal urea nitrogen.

$M$ any commercial turfgrass fertilizers are referred to as specialty fertilizers. These products contain nitrogen $(\mathrm{N})$, phosphorus $(\mathrm{P})$, and potassium $(\mathrm{K})$, in addition to organic materials such as plant hormones, humic substances, amino acids (AAs), or a combination thereof (Schmidt, 1999; Schmidt and Zhang, 1997). The addition of organic materials, specifically AAs, has been reported to improve plant growth compared with mineral nutrition alone (Ervin and Zhang, 2008; Schmidt et al., 2003). As a result, the use of specialty fertilizers has increased, whereas those containing AAs have surged in commercial availability (Aylward and Chief, 2005).

Received for publication 3 June 2019. Accepted for publication 30 July 2019.

Published online 20 September 2019.

${ }^{1}$ Department of Horticulture, Iowa State University, 106 Horticulture Hall, Ames, IA 50011

I.T.M. is the corresponding author. E-mail: imertz@ iastate.edu.

This is an open access article distributed under the CC BY-NC-ND license (https://creativecommons.org/ licenses/by-nc-nd/4.0/).

https://doi.org/10.21273/HORTTECH04423-19
AAs are the building blocks of proteins, enzymes, nucleic acids, antioxidants, and other secondary compounds necessary for life (Taiz and Zeiger, 2006). They contain an amino group $\left(\mathrm{NH}_{2}\right)$ that makes them a possible $\mathrm{N}$ source for plants. When foliarly applied, some AAs can enter the plant through leaf tissue, resulting in N uptake (Joy and Antcliff, 1966; Mäkelä et al., 1996). Furthermore, compared with industry standard urea $\mathrm{N}$, which must be converted to ammonium $\left(\mathrm{NH}_{4}^{+}\right)$by the enzyme urease before the $\mathrm{N}$ entering plant leaves and being assimilated into AA inside the plant (Hull et al., 2014), supplying the plant directly with AAs may be a more sustainable method of providing plants with $\mathrm{N}$.

Foliarly applied AAs enter the plant through openings in leaf cuticle tissue that are negatively charged (Stiegler et al., 2013). When the $\mathrm{pH}$ of an AA solution is below nine, the $\mathrm{N}$ functional group of AAs is positively charged (Lide, 1991), and this promotes movement of AAs through the negatively charged openings of leaf cuticle tissue (Stiegler et al., 2013). Additionally, AAs having a hydrophobic side-chain can easily enter the plant using diffusion forces (Schönherr, 1976).

Because of this, some AAs may be more effective than others as additives in foliarly applied fertilizers. Three AAs that can be plant absorbed using both ion uptake and diffusion forces are the BCAAs leucine, isoleucine, and valine. BCAAs could be effective additives in foliarly applied fertilization products because they have aliphatic nonpolar side chains and are relatively hydrophobic (Harper et al., 1984). We hypothesize that the hydrophobicity of these AAs will make them more mobile through the epicuticular wax and cutin of the leaf cuticle. According to Schönherr (1976), once through the cuticle and inside the plant, this hydrophobicity could promote further diffusion of the materials through the cell membranes of leaf tissues. Together, these characteristics favor plant absorption of BCAAs (Marschner, 1995, 2011; Stiegler et al., 2013; Totten et al., 2008).

Research on plant BCAA catabolism, as well as the effect of exogenously applied BCAA on plant growth, is limited; however, research on BCAA effects in humans has been studied, with a large emphasis being their effect on the rate of protein synthesis (Blomstrand et al., 2006; Kimball and Jefferson, 2001, 2006). The BCAAs have been demonstrated to increase muscle protein synthesis

\begin{tabular}{|c|c|c|c|}
\hline $\begin{array}{l}\text { Units } \\
\text { To convert U.S. to SI, } \\
\text { multiply by }\end{array}$ & U.S. unit & SI unit & $\begin{array}{l}\text { To convert SI to U.S., } \\
\text { multiply by }\end{array}$ \\
\hline 29.5735 & $\mathrm{fl} \mathrm{oz}$ & $\mathrm{mL}$ & 0.0338 \\
\hline 0.0929 & $\mathrm{ft}^{2}$ & $\mathrm{~m}^{2}$ & 10.7639 \\
\hline 9.3540 & $\mathrm{gal} / \mathrm{acre}$ & $\mathrm{L} \cdot \mathrm{ha}^{-1}$ & 0.1069 \\
\hline 2.54 & inch(es) & $\mathrm{cm}$ & 0.3937 \\
\hline 6.4516 & inch $^{2}$ & $\mathrm{~cm}^{2}$ & 0.1550 \\
\hline 1.1209 & $\mathrm{lb} / \mathrm{acre}$ & $\mathrm{kg} \cdot \mathrm{ha}^{-1}$ & 0.8922 \\
\hline 28.3495 & $\mathrm{oz}$ & $\mathrm{g}$ & 0.0353 \\
\hline$\left({ }^{\circ} \mathrm{F}-32\right) \div 1.8$ & ${ }^{\circ} \mathrm{F}$ & ${ }^{\circ} \mathrm{C}$ & $\left({ }^{\circ} \mathrm{C} \times 1.8\right)+32$ \\
\hline
\end{tabular}


of humans (Holeček, 2002; Kerksick et al., 2006; Pasiakos et al., 2011), which is related to the intake ratio of L to IL and V (Pasiakos et al., 2011; Stoppani, 2014, 2018). Because they can lead to an increase of muscle protein synthesis, BCAA products have increased for human bodybuilding and nutrition (Singh, 2017). Nonetheless, commercially available BCAA products often contain varying amounts of L to IL and V, and there is not a clear consensus on the optimal intake ratio (L:IL:V) (Stoppani 2014, 2018). One clear consensus is that all three BCAAs must be present in some amount, with L being the dominant material, for the benefit of increased muscle protein synthesis to occur. No such increase has been reported if any of these BCAAs are missing (Blomstrand et al., 2006; Kimball and Jefferson, 2001, 2006; Pasiakos et al., 2011).

The objectives of this study were to investigate the use of the BCAAs as an $\mathrm{N}$ source for fertilizing creeping bentgrass and to observe whether any additional benefits occur when BCAAs are applied in a complete three-way combination (L:IL:V).

\section{Materials and methods}

EXPERIMENTAL DESIGN AND APPLICATION OF TREATMENTS. The experiment was initiated in 2014 at the Iowa State University Charles V. Hall Greenhouses (Ames, IA), and conducted over two periods using a completely randomized design and four replications. Run 1 of the study was initiated on 7 Apr. and run 2 began 21 July. In each run, initial $\mathrm{N}$ applications were applied $14 \mathrm{~d}$ after seeding (DAS) and continued on 14-d intervals. Nitrogen sources consisted of l) $\mathrm{L}, 2) \mathrm{V}, 3) \mathrm{IL}, 4) \mathrm{L}+\mathrm{V}, 5$ ) $\mathrm{L}+\mathrm{IL}, 6) \mathrm{IL}+\mathrm{V}, 7) \mathrm{L}+\mathrm{IL}+\mathrm{V}$ (2:1:1), and 8) L + IL + V (4:1:1) (Table 1); 9) an untreated control [UTC (no N fertilizer)], and 10) equivalent urea $\mathrm{N}$ were included for comparisons. All $\mathrm{N}$ sources were evaluated at $\mathrm{N}$ application rates of 3.03 , $6.06,12.12$, and $24.24 \mathrm{lb} /$ acre $\mathrm{N}$ (Table 1).

In run 1 , treatment applications occurred on 21 Apr., 5 May, 19 May, and 2 June. In run 2, treatment applications occurred on 4 Aug., 18 Aug., l Sept., and 15 Sept. Nitrogen sources were applied foliarly using a handheld sprayer, and a carrier volume of $87 \mathrm{gal} / \mathrm{acre}$. Deionized water ( $\mathrm{pH} 5.8$ ) was used to dissolve $\mathrm{N}$ treatments into solution before application. To promote maximum foliar absorption of the materials, treatments were allowed to dry after applications before being watered in.

The BCAAs used in this study were purchased from Hard Eight Nutrition (Henderson, NV), and N content by weight was as follows: $\mathrm{L}$ and IL $10.7 \% \mathrm{~N}$, and $\mathrm{V} 12 \% \mathrm{~N}$. Nutritional content was also tested and verified by Waypoint Analytical (Memphis, TN).

ROOTING TUBES CONSTRUCTION AN D CREEPING BENT GRASS ESTABLISHMENT. A completely randomized design with four replications (148 total rooting tubes) was used during each run of the study. Rooting tubes were constructed using 1.25inch-diameter PVC pipe, a l-inchdiameter polyethylene insert, and modified methods originally described by Lehman and Engelke (1991). Each polyethylene insert was filled with a sand root zone to a depth of $60 \mathrm{~cm}$. The root zone particle analysis was $8.2 \%$ very coarse, $35.3 \%$ coarse, $44.3 \%$ medium, $11.9 \%$ fine, $0.1 \%$ very fine, and $0.2 \%$ silt/clay by volume, with a $\mathrm{pH}$ of 8.2. This sand met the physical specifications for a sand-based putting green root zone as specified by the U.S. Golf Association (Beard, 2002). The sand-filled polyethylene inserts were placed into 60-cm-long pieces of PVC pipe, which were secured to a greenhouse rack at an orientation of $45^{\circ}$.

Supplemental radiation was provided when daytime irradiance dropped below $200 \mu \mathrm{mol} \cdot \mathrm{m}^{-2} \cdot \mathrm{s}^{-1}$ to ensure a consistency of $16 \mathrm{~h}$ of light per day (LightScout Quantum Meter; Spectrum Technologies, Aurora, IL). Throughout the entirety of the study, peak daytime irradiance was 350 to $385 \mu \mathrm{mol} \cdot \mathrm{m}^{-2} \cdot \mathrm{s}^{-1} \quad($ mean $=330$ $\left.\mu \mathrm{mol} \cdot \mathrm{m}^{-2} \cdot \mathrm{s}^{-1}\right)$, air temperature was 22.3 to $23.6^{\circ} \mathrm{C}\left(\right.$ mean $\left.=22.8{ }^{\circ} \mathrm{C}\right)$, and relative humidity was $24.3 \%$ to $44.7 \%$ (mean $=35.6 \%)$.

Following rooting tube set up, slits were made to the bottom of each polyethylene insert for drainage to occur. '007' creeping bentgrass samples were established from seed (43.56 lb/acre). The application of a modified Hoagland's solution was made at the time of seeding to promote uniform germination (Carrow et al., 1975). The modified Hoagland's solution was $\mathrm{N}$ free, applied at a rate of $43.56 \mathrm{lb} /$ acre $P$. Tubes were mist watered with $2 \mathrm{~mL}$ four times per day until seeds began germinating, as determined visually. After germination, watering transitioned to $\mathrm{l}$ inch per week.

Creeping bentgrass plants were initially cut when the samples had reached a 1.3-inch height on average. Samples were maintained weekly at a 1 -inch height of cut, using hand shears. At the conclusion of the study, physical plant measurements were determined as described subsequently.

Data collection. From 49 DAS, samples were allowed to grow uncut through the duration of the study (63 DAS). Trimming was ceased to assess the effect of treatment on above-ground biomass growth. At 63 DAS, the polyethylene inserts were removed from PVC tubes and placed on a wire-mesh screen. Polyethylene inserts were separated from the root zone by cutting down one side and carefully removing them (Lehman and Engelke, 1991). Intact root zones were rinsed free of sand over the mesh screen using deionized water. Samples were severed at the crown by hand using scissors to separate roots and shoots, and then oven dried at $80{ }^{\circ} \mathrm{C}(24 \mathrm{~h})$ (Scientific Engineering Response Analytical Services, 1994) before weighing. The loss on ignition method was followed for establishment of root weights (Ball, 1964; Sluiter et al., 2008).

Before shoot weight measurements, the number of shoots was counted visually using modified methods described by Law et al. (2013). Average rooting and shoot length were also measured by hand at 63 DAS using a ruler.

Statistical analysis. Data were analyzed using the GLM procedure (SAS version 9.3; SAS Institute, Cary, $\mathrm{NC}$ ). Due to a nonsignificant interaction between $\mathrm{N}$-source and $\mathrm{N}$-rate, $\mathrm{N}$-source data were combined across rates, and the effect of $\mathrm{N}$-rate will be discussed independently. Orthogonal contrasts were used to compare each BCAA combination(s) to urea (Hoke et al., 1990). Mean separation was done using the Ryan-Einot-GabrielWelsch multiple range test at $\alpha=0.05$ (Hochberg and Tomhane, 1987; Mickey et al., 2004). Unless otherwise noted, all results have been 
Table 1. Description of the nitrogen $(\mathrm{N})$ sources and rates applied to creeping bentgrass growing in sand under greenhouse conditions at Ames, IA, in 2014.

\begin{tabular}{lcc}
\hline N source $^{\mathrm{z}}$ & $\mathbf{N}$ content $(\%)$ & $\mathbf{N}$ rates $(\mathbf{l b} / \mathbf{a c r e})^{\mathbf{y}}$ \\
\hline Untreated control & 0 & 0 \\
Urea & 46 & $3.03,6.06,12.12,24.24$ \\
Leucine (L) & 10.7 & $3.03,6.06,12.12,24.24$ \\
Isoleucine (IL) & 10.7 & $3.03,6.06,12.12,24.24$ \\
Valine (V) & 12 & $3.03,6.06,12.12,24.24$ \\
L + IL & 10.7 & $3.03,6.06,12.12,24.24$ \\
$\mathrm{~L}+\mathrm{V}$ & 11.4 & $3.03,6.06,12.12,24.24$ \\
$\mathrm{IL}+\mathrm{V}$ & 11.4 & $3.03,6.06,12.12,24.24$ \\
$\mathrm{~L}: \mathrm{IL}: \mathrm{V}(2: 1: 1)$ & 11.1 & $3.03,6.06,12.12,24.24$ \\
L:IL:V $(4: 1: 1)$ & 11.1 & $3.03,6.06,12.12,24.24$ \\
\hline
\end{tabular}

${ }^{\mathrm{z}} \mathrm{L}$, IL, and V purchased from Hard Eight Nutrition (Henderson, NV).

${ }^{y} \mathrm{~N}$ applications for run 1 were applied chronologically on the following dates in 2014:21 Apr., 5 May, 19 May, and 2 June. In run 2, N was applied chronologically on the following dates in 2014: 4 Aug., 18 Aug., 1 Sept., and 15 Sept. During each run of the study, a total of $4 \mathrm{~N}$ applications were made using each $\mathrm{N}$-source and $\mathrm{N}$-rate; $1 \mathrm{lb} /$ acre $=1.1209 \mathrm{~kg} \cdot \mathrm{ha}^{-1}$.

combined between runs and are presented as a single dataset due to a nonsignificant interaction between treatment and runs.

\section{Results}

Rooting length measurements were unaffected by $\mathrm{N}$-source or $\mathrm{N}$ rate at 63 DAS. Creeping bentgrass roots extended to the bottom of rooting tubes, regardless of $\mathrm{N}$-source or N-rate. Compared with the UTC, creeping bentgrass receiving $\mathrm{N}$-applications had greater root weight measurements, regardless of $\mathrm{N}$-source (Table 2). All BCAA combinations resulted in equal root weights compared with urea, and there were no differences between BCAA combinations. A difference in $\mathrm{N}$-rate was detected between fertilized creeping bentgrass and the unfertilized control; however, where $\mathrm{N}$ was applied, N-rate had no effect on creeping bentgrass root weight (Table 3 ).

Shoot weight was greatest in creeping bentgrass receiving applications of urea, 2:1:1, and 4:1:1 (L:IL:V), where shoot weight was increased by $142 \%, 123 \%$, and $140 \%$, respectively, compared with the UTC (Table 2). When BCAA were applied as $\mathrm{L}$ or $\mathrm{V}$, creeping bentgrass shoot weight was less than equivalent urea N. Orthogonal contrasts, which excludes the UTC, indicate that all single and two-way BCAA combinations resulted in less shoot weight compared with equivalent urea $\mathrm{N}$ (Table 2). Nitrogen rate had no effect on creeping bentgrass shoot weight.

Samples receiving urea $\mathrm{N}$ had greater shoot height measurements than all other treatments (Table 2).
Each BCAA combination increased shoot height compared with the untreated control, and there were no differences between BCAA combinations. Nonetheless, creeping bentgrass shoot height was still 22\% less on average across all BCAA combinations compared with urea N. A difference in $\mathrm{N}$-rate was detected between fertilized creeping bentgrass and the unfertilized control; however, there were no differences in N-rate when $\mathrm{N}$ was applied (Table 3 ).

When BCAAs were applied as 2:1:1 and 4:1:1, creeping bentgrass shoot density was increased by $24 \%$ and $32 \%$, respectively, compared with urea N (Table 2). Orthogonal contrasts between each BCAA combination and urea, excluding the UTC, revealed that creeping bentgrass shoot density was decreased compared with urea $\mathrm{N}$ for the IL and IL $+\mathrm{V}$ combinations. Additionally, IL was the only BCCA N-source that failed to increase creeping bentgrass shoot density over the UTC (Table $2)$. Nitrogen rate led to a difference in shoot height only in the absence of $\mathrm{N}$, but where $\mathrm{N}$ was applied, increasing or decreasing the N-rate had no effect on shoot height (Table 3 ).

\section{Discussion}

Creeping bentgrass receiving applications of BCAA $\mathrm{N}$ resulted in equivalent root and shoot weights compared with urea $\mathrm{N}$ for all BCAA combinations other than $\mathrm{L}$ and $\mathrm{V}$. Although N-source had little effect on biomass accumulation measurements, an additional benefit of increased shoot density was observed when BCAAs were applied in a three- way combination, whereas no such increases were observed when BCAAs were applied as a single or two-way combination. This result was similar to observations in humans, where a three-way BCAA combination was reported to increase protein synthesis compared with single and two-way BCAA combinations. It is possible that BCAA applied directly to the plant are having a similar effect on plant protein synthesis; however, that is only speculation. Future studies will investigate this scenario so that we may better understand the effect three-way BCAA combinations are having on plant growth. Additionally, future studies will also investigate how BCAAs could best be incorporated into an existing fertilizer program and how BCAAs can be used the most effectively by turfgrass managers. Nonetheless, on the basis of these results, using BCAA 2:1:1 or 4:1:1 (L:IL:V) applications can increase creeping bentgrass shoot density compared with urea- $\mathrm{N}$, regardless of N-rate used.

The N-rate had little effect on overall creeping bentgrass performance. Where N-rate did have an effect, differences were often a result of fertilized versus unfertilized creeping bentgrass. On average, $\mathrm{N}$ increased creeping bentgrass root weight, shoot height, and shoot density compared with creeping bentgrass receiving no N. For those same measurements, no increases were observed as $\mathrm{N}$-rate increased beyond $3.03 \mathrm{lb} /$ acre $\mathrm{N}$, indicating that there is no need to go beyond the $3.03 \mathrm{lb} /$ acre $\mathrm{N}$ rate when using BCAA as an N-source.

Overall, BCAAs appear to be suitable for use as an $\mathrm{N}$-source on creeping bentgrass. Compared with urea, shoot height (for all treatments) and shoot weight (for single BCAA and two-way combinations) were negatively affected. When applied as a three-way combination, creeping bentgrass biomass measurements were equal to urea, and shoot density was increased. The observation of three-way BCAA combinations increasing shoot density, without increasing biomass is speculated to be a plant growth regulating (PGR) effect, above that provided by $\mathrm{N}$ alone. Previously, AA applications have been reported to affect endogenous plant hormone levels (Aamlid et al., 2017; Carbonera et al., 1989; Merewitz 
Table 2. Effects of nitrogen $(\mathrm{N})$ source on creeping bentgrass rooting length, rooting weight, shoot height, shoot weight, and shoot density after growing in sand for $63 \mathrm{~d}$ under greenhouse conditions at Ames, IA, in 2014. ${ }^{\mathrm{z}}$

\begin{tabular}{|c|c|c|c|c|c|}
\hline $\mathrm{N}$ source $^{\mathrm{y}}$ & $\begin{array}{l}\text { Root length } \\
(\mathrm{cm})^{\mathrm{x}}\end{array}$ & $\begin{array}{l}\text { Root wt } \\
(\mathrm{g})^{\mathrm{w}}\end{array}$ & $\begin{array}{l}\text { Shoot ht } \\
(\mathrm{cm})^{\mathrm{x}}\end{array}$ & $\begin{array}{c}\text { Shoot wt } \\
(\mathrm{g})^{\mathrm{v}}\end{array}$ & $\begin{array}{c}\text { Shoot density } \\
\left(\text { no. } / 2.85 \mathrm{~cm}^{2}\right)^{u}\end{array}$ \\
\hline Untreated control & 59.6 & $0.11 b^{t}$ & $4.5 \mathrm{~d}$ & $0.15 \mathrm{c}$ & $27.0 \mathrm{e}$ \\
\hline Urea & 56.3 & $0.21 \mathrm{a}$ & $7.8 \mathrm{a}$ & $0.36 \mathrm{a}$ & $38.6 \mathrm{bc}$ \\
\hline Leucine (L) & 59.2 & $0.20 \mathrm{a}$ & $6.2 \mathrm{bc}$ & $0.18 \mathrm{c}$ & $39.1 \mathrm{bc}$ \\
\hline Isoleucine (IL) & 59.8 & $0.20 \mathrm{a}$ & $5.9 \mathrm{bc}$ & $0.27 \mathrm{abc}$ & $31.4 \mathrm{de}$ \\
\hline Valine $(\mathrm{V})$ & 59.8 & $0.22 \mathrm{a}$ & $6.4 \mathrm{~b}$ & $0.20 \mathrm{bc}$ & $36.9 \mathrm{bc}$ \\
\hline $\mathrm{L}+\mathrm{IL}$ & 57.7 & $0.23 \mathrm{a}$ & $5.9 \mathrm{bc}$ & $0.24 \mathrm{abc}$ & $41.2 \mathrm{~b}$ \\
\hline $\mathrm{L}+\mathrm{V}$ & 55.6 & $0.20 \mathrm{a}$ & $5.7 \mathrm{c}$ & $0.28 \mathrm{abc}$ & $41.8 \mathrm{~b}$ \\
\hline $\mathrm{IL}+\mathrm{V}$ & 59.3 & $0.20 \mathrm{a}$ & $6.5 \mathrm{~b}$ & $0.28 \mathrm{abc}$ & $34.7 \mathrm{~cd}$ \\
\hline L:IL:V (2:1:1) & 59.6 & $0.20 \mathrm{a}$ & $6.2 \mathrm{bc}$ & $0.33 \mathrm{ab}$ & $47.7 \mathrm{a}$ \\
\hline L:IL:V (4:1:1) & 58.4 & $0.22 \mathrm{a}$ & $6.2 \mathrm{bc}$ & $0.36 \mathrm{a}$ & $50.9 \mathrm{a}$ \\
\hline \multicolumn{6}{|l|}{ Contrasts } \\
\hline L vs. urea & NS & NS & $* * *$ & $* * *$ & NS \\
\hline IL vs. urea & NS & NS & $* * *$ & * & $* * *$ \\
\hline V vs. urea & NS & NS & $* * *$ & * & NS \\
\hline $\mathrm{L}+\mathrm{IL}$ vs. urea & NS & NS & $* * *$ & * & NS \\
\hline $\mathrm{L}+\mathrm{V}$ vs. urea & NS & NS & $* * *$ & * & NS \\
\hline $\mathrm{IL}+\mathrm{V}$ vs. urea & NS & NS & $* * *$ & $*$ & * \\
\hline 2:1:1 vs. urea & NS & NS & $* * *$ & NS & $* * *$ \\
\hline $4: 1: 1$ vs. urea & NS & NS & $* * *$ & NS & $* * *$ \\
\hline
\end{tabular}

${ }^{z}$ Due to a nonsignificant interaction between $\mathrm{N}$-source and $\mathrm{N}$-rates, results have been combined across rates by $\mathrm{N}$ source. The study was conducted over two runs in 2014. Results have been combined across runs. Run 1 occurred from 7 Apr. to 9 June, and run 2 from 21 July to 22 Sept.

${ }^{y} \mathrm{~L}, \mathrm{IL}$, and V purchased from Hard Eight Nutrition (Henderson, NV)

${ }^{x}$ Root length and shoot height measured using a ruler; $1 \mathrm{~cm}=0.3937$ inch.

${ }^{w}$ Root weight as determined by loss on ignition method; $1 \mathrm{~g}=0.0353 \mathrm{oz}$.

vven-dry weight of shoots.

"Average number of creeping bentgrass shoots counted visually; l shoot $/ 2.85 \mathrm{~cm}^{2}=2.2637$ shoots $/$ inch ${ }^{2}$.

${ }^{t}$ Mean separation was done using the Ryan-Einot-Gabriel-Welsch multiple range test at $P=0.05$ (lowercase letters).

Ns, ${ }^{*},{ }^{*} *$ Nonsignificant or significant at $P \leq 0.05$ or 0.001 , respectively.

Table 3. Effects of nitrogen $(\mathrm{N})$ rate on creeping bentgrass rooting length, root weight, shoot height, shoot weight, and shoot density after growing in sand for $63 \mathrm{~d}$ under greenhouse conditions at Ames, IA, in $2014 .^{\mathrm{z}}$

\begin{tabular}{lccccc}
\hline $\begin{array}{l}\text { N rate } \\
(\mathbf{l b} / \text { acre })^{\mathbf{y}}\end{array}$ & $\begin{array}{c}\text { Root length } \\
(\mathbf{c m})^{\mathbf{x}}\end{array}$ & $\begin{array}{c}\text { Root wt } \\
(\mathbf{g})^{\mathbf{w}}\end{array}$ & $\begin{array}{c}\text { Shoot ht } \\
(\mathbf{c m})^{\mathbf{x}}\end{array}$ & $\begin{array}{c}\text { Shoot wt } \\
(\mathbf{g})^{\mathbf{v}}\end{array}$ & $\begin{array}{c}\text { Shoot density } \\
\left(\mathbf{n o} / \mathbf{2 . 8 5} \mathbf{c m}^{2}\right)^{\mathbf{u}}\end{array}$ \\
\hline 0 & 59.6 & $0.11 \mathrm{~b}^{\mathrm{t}}$ & $4.5 \mathrm{~b}$ & 0.15 & $27.0 \mathrm{~b}$ \\
3.03 & 57.8 & $0.20 \mathrm{a}$ & $6.1 \mathrm{a}$ & 0.25 & $37.7 \mathrm{a}$ \\
6.06 & 58.7 & $0.23 \mathrm{a}$ & $6.4 \mathrm{a}$ & 0.27 & $39.8 \mathrm{a}$ \\
12.12 & 58.9 & $0.21 \mathrm{a}$ & $6.4 \mathrm{a}$ & 0.28 & $41.7 \mathrm{a}$ \\
24.24 & 58.3 & $0.19 \mathrm{a}$ & $6.2 \mathrm{a}$ & 0.29 & $41.9 \mathrm{a}$ \\
\hline
\end{tabular}

${ }^{\mathrm{z}}$ Due to a nonsignificant interaction between $\mathrm{N}$-rate and $\mathrm{N}$-sources, results have been combined across sources by $\mathrm{N}$-rate. The study was conducted over two runs in 2014 . Results have been combined across runs. Run 1 occurred from 7 Apr. to 9 June and run 2 from 21 July to 22 Sept.

${ }^{\mathrm{y}} \mathrm{l} \mathrm{lb} / \mathrm{acre}=1.1209 \mathrm{~kg} \cdot \mathrm{ha}^{-1}$.

${ }^{x}$ Root length and shoot height measured using a ruler; $1 \mathrm{~cm}=0.3937$ inch.

${ }^{\text {w }}$ Root weight as determined by loss on ignition method; $1 \mathrm{~g}=0.0353 \mathrm{oz}$.

voven-dry weight of shoots.

${ }^{u}$ Average number of creeping bentgrass shoots counted visually; 1 shoot $/ 2.85 \mathrm{~cm}^{2}=2.2637$ shoots $/$ inch $^{2}$.

${ }^{t}$ Mean separation was done using the Ryan-Einot-Gabriel-Welsch multiple range test at $P=0.05$ (lowercase letters).

et al., 2012), and this demonstrates how AA applications can result in PGR activity.

Being able to increase the shoot density of creeping bentgrass, especially when maintained at puttinggreen height, with BCAA applications could be a valuable tool for golf-course superintendents. These applications could be used to increase or promote putting-green performance and could be a way of improving older creeping bentgrass cultivars with innately low shoot density, without completely regrassing the surface. These applications could also be used to increase or promote surface uniformity during periods of high stress. Creeping bentgrass is known to experience decline throughout the season, and as a result, the shoot density and surface uniformity can also decrease. These effects can lead to an inconsistent ball roll on putting greens and to golfers having an overall negative experience.

Future work should attempt to understand the effect of BCAA on creeping bentgrass shoot density and work to investigate whether BCAA applications are resulting in PGR activity. To better understand plant catabolism of BCAA, methods to better track the effect BCAA are having on plant growth using the 3.03 $\mathrm{lb} /$ acre $\mathrm{N}$ rate will be implemented. Additionally, future studies will investigate the effect of BCAA on creeping bentgrass growth when maintained at putting green height.

\section{Literature cited}

Aamlid, T.S., A. Kvalbein, and T. Petterson. 2017. Evaluation of an amino-acid-based fertilizer for grow-in of creeping bentgrass putting greens. Crop Sci. 57(S1):357S360 s.

Aylward, L. and I. Chief. 2005. More superintendents are using biostimulants and trusting in them, companies say. Golfdom 61(10):54-58

Ball, D. 1964. Loss-on-ignition as an estimate of organic matter and organic carbon in non-calcareous soils. J. Soil Sci. 15(1):84-92.

Beard, J.B. 2002. Turf management for golf courses. Ann Arbor Press, Chelsea, MI.

Blomstrand, E., J. Eliasson, H.R. Karlsson, and R. Köhnke. 2006. Branched-chain amino acids activate key enzymes in protein synthesis after physical exercise. J. Nutr. 136(1):269S-273S

Carbonera, D., P. Iadarola, and R. Cella. 1989. Effect of exogenous amino acids on the intracellular content of proline and other amino acids in Daucus carota cells. Plant Cell Rep. 8(7):422-424.

Carrow, R., P. Rieke, and B. Ellis. 1975. Growth of turfgrasses as affected by soil phosphorus and arsenic. Soil Sci. Soc. Amer. J. 39(6):1121-1124.

Ervin, E.H. and X. Zhang. 2008. Applied physiology of natural and synthetic plant growth regulators on turfgrasses, p. 171202. In: M. Pessarakli (ed.). Handbook of turfgrass management and physiology. CRC Press, Boca Raton, FL.

Harper, A., R. Miller, and K. Block. 1984. Branched-chain amino acid metabolism. Annu. Rev. Nutr. 4(1):409-454. 
Hochberg, Y. and A. Tamhane. 1987. Multiple comparison procedures. Wiley, Hoboken, NJ.

Hoke, R.A., J.P. Giesy, and J.R. Adams. 1990. Use of linear orthogonal contrasts in analysis of environmental data. Environ. Toxicol. Chem. 9(6):815-819.

Holeček, M. 2002. Relation between glutamine, branched-chain amino acids, and protein metabolism. J. Nutr. 18(2):130133.

Hull, R.J., H. Liu, and N. Menchyk. 2014. How turfgrasses use urea-nitrogen. 2 Feb. 2019. <https://www.golfdom.com/ how-turfgrasses-use-urea-nitrogen $/>$.

Joy, K. and A. Antcliff. 1966. Translocation of amino-acids in sugar beet. Nature 211(5045):210.

Kerksick, C., C. Rasmussen, S.L. Lancaster, B. Magu, P. Smith, C. Melton, M. Greenwood, A. Almada, C. Earnest, and R. Kreider. 2006. The effects of protein and amino acid supplementation on performance and training adaptations during ten weeks of resistance training. J. Strength Cond. Res. 20(3):643-653.

Kimball, S.R. and L.S. Jefferson. 2001. Regulation of protein synthesis by branchedchain amino acids. Curr. Opin. Clin. Nutr. Metab. Care 4(1):39-43.

Kimball, S.R. and L.S. Jefferson. 2006. Signaling pathways and molecular mechanisms through which branched-chain amino acids mediate translational control of protein synthesis. J. Nutr. 136(1):227S$231 S$.

Law, Q.D., M.A. Jones, A.J. Patton, and N.E. Christians. 2013. Influence of an amino acid complex on the growth of Agrostis stolonifera cv. Penncross. Intl. Turfgrass Soc. Res. J. 12:485-489.

Lehman, V. and M. Engelke. 1991. Heritability estimates of creeping bentgrass root systems grown in flexible tubes. Crop Sci. 31(6):1680-1684.

Lide, D.R. 1991. Handbook of chemistry and physics. 72nd ed. CRC Press, Boca Raton, FL.

Mäkelä, P., P. Peltonen-Sainio, K. Jokinen, E. Pehu, H. Setälä, R. Hinkkanen, and S. Somersalo. 1996. Uptake and translocation of foliar-applied glycinebetaine in crop plants. Plant Sci. 121(2):221-230.

Marschner, H. 1995. Marschner's mineral nutrition of higher plants. Elsevier Ltd., London, UK.

Marschner, H. 2011. Marschner's mineral nutrition of higher plants. 2nd ed. Elsevier, London, UK.

Merewitz, E.B., H. Du, W. Yu, Y. Liu, T. Gianfagna, and B. Huang. 2012. Elevated cytokinin content in ipt transgenic creeping bentgrass promotes drought tolerance through regulating metabolite accumulation. J. Expt. Bot. 63(3):13151328.

Mickey, R., O. Dunn, and V. Clark. 2004. Applied statistics: Analysis of variance and regression. Wiley, Hoboken, NJ.

Pasiakos, S.M., H.L. McClung, J.P. McClung, L.M. Margolis, N.E. Andersen, G.J. Cloutier, M.A. Pikosky, J.C. Rood, R.A. Fielding, and A.J. Young. 2011. Leucine-enriched essential amino acid supplementation during moderate steady state exercise enhances postexercise muscle protein synthesis. Amer. J. Clin. Nutr. 94(3):809-818.

Schmidt, R. 1999. Biostimulant products: What research has shown: How they work. 1998 Rutgers Turfgrass. Proc. New Jersey Turfgrass Exposition 30:11-17.

Schmidt, R., E. Ervin, and X. Zhang. 2003. Questions and answers about biostimulants. Golf Course Mgt. 71(6):91-94.
Schmidt, R. and X. Zhang. 1997. Advanced concepts in turfgrass nutrition. Turfgrass Trends 6(2):9-17.

Schönherr, J. 1976. Water permeability of isolated cuticular membranes: The effect of $\mathrm{pH}$ and cations on diffusion, hydrodynamic permeability and size of polar pores in the cutin matrix. Planta 128(2):113-126.

Scientific Engineering Response Analytical Services. 1994. Standard operating procedures: Plant biomass determination. 16 Nov. 2018. <https://clu-in.org/ download/ert/2034-R00.pdf>.

Singh, R. 2017. Global BCAA market projected to reach 290 million US\$ by 2025- QY Research, Inc. 5 Aug. 2019. <http://www.digitaljournal.com/pr/ 3970330>

Sluiter, A., B. Hames, R. Ruiz, C. Scarlata, J. Sluiter, and D. Templeton. 2008. Determination of ash in biomass. Natl. Renewable Energy Lab. TP-510.

Stiegler, C., M.D. Richardson, D.E. Karcher, T.L. Roberts, and R.J. Norman. 2013. Foliar absorption of various inorganic and organic nitrogen sources by creeping bentgrass. Crop Sci. 53(3):1148-1152.

Stoppani, J. 2014. Encyclopedia of muscle \& strength. Human Kinetics, Champaign, IL.

Stoppani, J. 2018. Encyclopedia of muscle \& strength. 2nd ed. Human Kinetics, Champaign, IL.

Taiz, L. and E. Zeiger. 2006. Plant physiology. 6th ed. Oxford Press, New York, NY.

Totten, F.W., H. Liu, L.B. McCarty, C.M. Baldwin, D.G. Bielenberg, and J.E. Toler. 2008. Efficiency of foliar versus granular fertilization: A field study of creeping bentgrass performance. J. Plant Nutr. 31(5):972-982. 